\title{
A Review on Bacillus Cereus in Africa's Locally Produced Foods
}

\author{
N'Guessan Elise, \\ Cissé Mohamed,
}

University Peleforo Gon Coulibaly Korhogo, Department of Biochemistry, Research of Biological Sciences, Korhogo, Côte d'Ivoire

\section{Bakayoko Souleymane,}

Pasteur Institute of Ivory Coast, Food Microbiology Laboratory, Abidjan

\section{Sindic Marianne,}

University of Liege, Gembloux Agro-Bio Tech, Laboratory of Agro-food Quality and Safety, Analysis, Quality and Risk Unit, Passage des Déportés, Gembloux, Belgium

\section{Doi: 10.19044/esj.2019.v15n9p228 URL:http://dx.doi.org/10.19044/esj.2019.v15n9p228}

\begin{abstract}
Bacillus cereus (B. cereus) is known to be responsible for food borne infections in humans and it is attributable to several foods. However, in developing countries, particularly in Africa, the prevalence of food borne infections attributable to this bacterium is difficult to assess accurately. This is because illness cases are nearly officially not reported. This paper focuses on foods contamination by B. cereus in Africa. A large number of foods, including street, fermented and children's foods, with a high rate of $B$. cereus have been revealed. Some of this $B$. cereus produces the emetic toxin, which is capable of causing fatal infections. Although this toxin seems to be less accumulated in acidified foods as well as in foods with low $\mathrm{pH}$ and low water activity, concern should be raised about the frequently poor sanitary conditions around the production and vending sites in the urban areas of developing countries. These conditions can increase $B$. cereus multiplication and toxin production, as well as infecting cereal-based infant food formulas, which support significant cereulide levels.
\end{abstract}

Keywords: Bacillus cereus, street foods, fermented foods, Africa 


\section{Introduction}

Bacillus cereus is a ubiquitous Gram-positive, facultative anaerobic and rod-shaped bacterium. It is increasingly recognized as an important food borne pathogen causing diarrhea, an emetic food poisoning with even fatal outcomes (Malher et al., 1997; Schulz et al., 2015; Glasset et al., 2016). In 2016, the existence of a discrete clade of the $B$. cereus group was found within tropical Africa, capable of causing anthrax-like disease which has been reported and it shows the dangerousness of this bacterium (Antonation et al., 2016). Furthermore, the existence of bacteria is suspected to be a highly pathogenic $B$. cereus in Zambia, and the possibility of an outbreak caused by highly pathogenic B. cereus has been identified (Ogawa et al., 2015).

The diarrhea syndrome is due to a combination of various toxins (Michelet \& Mahillon, 2003). However, emesis is caused by a single heatstable toxin, which is the cereulide produced in the food (Agata et al., 1995; Ehling-Schulz et al., 2004; Rajkovic et al., 2008).

Several death cases related to the emetic B. cereus have been reported in developed countries (Dierick et al., 2005; Shiota et al., 2010; Naranjo et al., 2011). Indeed, the prevalence of food borne poisoning outbreaks related to $B$. cereus is documented in these countries (EFSA, 2005). However, in developing countries, particularly in Africa, the actual number of food borne infections attributable to $B$. cereus is difficult to assess accurately. This is because, illness cases are nearly officially not reported.

Starchy foods like rice and pasta are mostly associated with emetic food poisoning (Naranjo et al., 2011). Rice is implicated in $95 \%$ of the $B$. cereus emetic food poisoning cases (Altayar \& Sutherland, 2006; EhlingSchulz et al., 2004). Furthermore, many other foods such as beef, poultry, vanilla sauce, pasteurized cream, milk pudding, milk product, pasteurized milk, and dairy products can support the $B$. cereus emetic toxin production (Kroten et al., 2010; Schoeni \& Wong, 2005; Delbrassinne et al., 2011). It must be noted that most of these foods implicated in food poisoning or which allowed the $B$. cereus emetic toxin production are consumed in different parts of African countries. In sub-Saharan Africa for example, cereals are considered one of the most important sources of nutrients, and young children below 5 years often receive some cereal-based gruels as complementary foods for breast feeding. These foods are produced in traditional production units under poor sanitary conditions (Honfoga et al., 2003; Mouquet-Rivier et al., 2008; Humblot et al., 2012).

According to Cissé et al. (2018), sorghum and millets constitute the main source of nutrition in diets of people living in the semi-arid regions of Africa and flour is one of the most consumed foods in Cameroon (EngleStone et al., 2012). Furthermore, in 2014, Ghosh et al. reported the 
implementation of small infant flour production companies, in many developing countries, to make locally produced infant flours available.

Since several food poisoning have been associated to B. cereus, and the health of infants and young children is at stake, it is relevant to have an overview of the prevalence of this bacterium in different foods in Africa.

\section{Bacillus Cereus in African Fermented Foods}

Some food condiments produced by alkaline fermentation constitute an important source of protein and are an essential part of the diet in West African countries, such as Burkina Faso and Benin (Kabore' et al., 2013; Kpikpi et al., 2014; Thorsen et al., 2015; Qian et al., 2015).

Many fermented foods are known, while some serve as main course meals, others serve as beverages and almost all humans are exposed to fermented foods in many forms.

Several studies have been reported on the health-promoting properties of fermented foods such as anti-inflammation, anticancer, and antioxidant properties. Also, fermented foods may improve intestinal and extra intestinal health. Furthermore, the folates, essential vitamins (B9) could be increased in foods during fermentation (Sivamaruthi et al., 2018; Kok et al., 2018).

However, most fermented foods have health-promoting benefits, bacterial species belonging to Bacillus cereus "sensu lato" (sl) group may occur in high numbers, or even be dominant in traditional fermented African foods (Oguntoyinbo \& Oni, 2004; Azokpota et al., 2007; Agbobatinkpo et al., 2013; Park et al., 2016).

Thus, after investigating fermented African locust bean-based condiments (Parkia biglobosa) produced in Benin, Thorsen et al. (2010) isolated Nineteen $B$. cereus group strains and seven of them produced cereulide. According to these authors, no reports on food poisoning from the consumption of the fermented condiments exist. Also, in 2012, Humblot et al. isolated high count of Bacillus cereus from cereal-based fermented slurries, which is used to prepare infant foods in an African context. B. cereus virulence genes were characterized in 60 isolates from 26 traditional cerealbased foods. Seventy-two and $38 \%$ of isolates were positive for the complete set of genes coding for hemolysin BL and nonhemolytic enterotoxin, respectively. This suggested a high enterotoxigenic potential for these foodborne isolates. Authors, however, suggested an inadequately controlled fermentation, resulting in conditions that would permit growth in some instance of pathogenic bacteria such as B. cereus. Fortunately, no potentially emetic toxin-producing strains were detected in this case.

In the same vein, Thorsen et al. (2015) isolated fifty-three B. cereus sensu lato from traditional West African food condiment. The number among them has been identified as cereulide producers. Within these conditions, 
those foods represent a major risk factor in emetic food poisoning. On another note, Bacillus cereus was detected in $95 \%$ of 50 tested samples of Nigerian traditional fermented dairy foods (Oguntoyinbo \& Kintum, 2015) and in fermented alcoholic beverages (Jeon et al., 2015).

The high incidence of detection $(20 \%)$ of possibly pathogenic $B$. cereus strains in a traditional fermented soup condiment from Nigeria, and this brings to light the potential health risk incurred by consumer (Oguntoyinbo et al., 2010).

In the knowledge that Bacillus species are among the common microorganisms involved in the fermentation process, the modernization process which involves developing appropriate steps such as starter culture production, controlled multi-step fermentation, and fermented functional foods production is recommended to obtain an enhanced health beneficial fermented product (Gadaga et al., 2004; Marco et al., 2017; Sivamaruthi et al., 2018).

Furthermore, the importance of fermented foods in African's eating habits and the frequently used cereal-based fermented foods as complementary foods for infants and young children in Africa should be taken in consideration (Tou et al., 2006). Also, the preparation of these foods should be carried out under appropriate hygienic conditions.

\section{Bacillus Cereus in Africa's Street Foods}

Ready-to-eat foods that are prepared and/or sold by vendors in public places or informal sector, commonly known as "street foods" (Hanashiro et al., 2005; Steyn et al., 2011; Alimi, 2016), are very popular in developing countries where a nutrition transition is underway in urban areas.

For many people with limited means, street foods are the most accessible way of obtaining a nutritionally balanced meal outside the home as long as the consumer is informed and capable of choosing an appropriate combination of foods (FAO, 2009). Even if these street foods ensure food security for low-income group urban populations and make an important contribution to employment (Kharel et al., 2010; Ekanem et al., 1998; Kharel et al., 2016), their cooking and sales operations are often unhygienic, particularly in developing countries. Thus, in 2016, the microbiological analysis of Soy wara, a common ready-to-eat food products and sale in Nigeria, highlighted the contamination of this food by different pathogens, including B. cereus (Akanbi \& Usoh, 2016). The determination of microbial load and pathogenic organisms in street meat by Haileselassie et al. (2013) showed mean values of $4.3 \times 10^{6} \mathrm{cfu} / \mathrm{g}$, and bacteria. B. cereus was one of the main isolated pathogens. Furthermore, after analyzing 148 point-of-sale composite street food samples in Gaborone, Botswana between June 2001 and May 2002, the B. cereus levels is as high as $9.1 \mathrm{log}$ CFU/g and 59.6\% of 
enterotoxigenic B. cereus was determined (Murindamombe et al., 2005). This bacterium was also isolated from 511 menu items, classified as breakfast/snack foods, main dishes, sauces, and cold dishes sold on streets of Accra, as part of an investigation on food quality and factors predisposing to their contamination. According to the authors, street foods can be sources of enteropathogens (Mensah et al., 2002). It must be noted that the risk of food poisoning from street food remains a threat in many parts of the world, especially microbiological contamination. Bacillus cereus contamination of raw milk produced on traditional dairy farms in Abidjan (Ivory Coast) from farm to retail was estimated at $27 \%$ and $41 \%$ respectively, for the udder milk samples and from seller's pooled milk (Yobouet et al., 2013). Given the high degree of milk consumption, there is a risk of exposure to B. cereus and therefore the probability of food poisoning caused by this bacterium is high. Also, it showed that "the attiéké", a popular food in Ivory Coast, could be a source of contamination by $B$. cereus given the presence of a high rate of this bacterium in the "Attiéké" (Yobouet et al., 2016). The temperatures used in cooking this food are high enough to kill the vegetative cells, but the resistant $B$. cereus spores can survive. Thus, handling after cooking, predisposes the latter to recontamination (Umoh \& Oddoba, 1999; Yobouet et al., 2016; Buliyaminu, 2016).

\section{Conclusion}

In this review, the presence of $B$. cereus in fermented foods and street foods in Africa was highlighted. Even if no reports on food poisoning from the consumption of the fermented condiments exist, most of these foods often contain high level of $B$. cereus and some of them produce emetic toxin. Although this toxin seems to be less accumulated acidified foods, concern should be raised as regards to cereal-based infant food formulas, which support significant cereulide levels. Furthermore, fatal cases of infection due to the B. cereus emetic toxin which occurred in Europe and Asia in the last two decades should be taken into consideration, and the contamination of food by this bacterium needs more attention in Africa. This study also contributes to the understanding of the risk associated with the presence of $B$. cereus in traditional fermented foods, as well as in street foods produced in poor conditions, in Africa.

\section{References:}

1. Agata, N., Ohta, M., Mori, M., \& Isobe, M. (1995). A novel dodecadepsipeptide, cereulide, is an emetic toxin of Bacillus cereus. FEMS Microbiol Lett.129: 17-20.

2. B, (2016). Risk factors in street food practices in developing countries: A review. FSHW. 5 : $141-148$. 
3. Altayar, M. \& Sutherland, AD. (2006). Bacillus cereus is common in the environment but emetic toxin producing isolates are rare. $J$ Appl Microbiol. 100: 7-14.

4. Antonation, KS., Grützmacher, K., Dupke, S., Mabon, P., Zimmermann, F., Lankeste, F., Peller, T., Feistner, A., Todd, A., Herbinger, L., de Nys, HM., Muyembe-Tamfun, JJ., Karhemere, S., \& Leendertz, FH. (2016). Bacillus cereus Biovar Anthracis Causing Anthrax in Sub-Saharan Africa - Chromosomal Monophyly and Broad Geographic Distribution. Negl Trop Dis. 10: e0004923.

5. Akanbi \& Usoh (2016). Safety of Street-Vended Soy Wara in Nigeria. J Food Prot, 79 : 169-73.

6. Azokpota, P., Møller, PL., Hounhouigan, JD., \& Jakobsen, M. (2007). Biodiversity of predominant Bacillus isolated from afitin, iru and sonru at different fermentation time. IJBCS. 1:211-222.

7. Buliyaminu, AA. (2016). Risk factors in street food practices in developing countries: A review. Food Science and Human Wellness. 5: 141-148.

8. Cisse, F., Erickson, DP., Hayes, MR., Opekun, AR., Nichols, OL., \& Hamaker, BR. (2018). Traditional Malian Solid Foods Made from Sorghum and Millet Have Markedly Slower Gastric Emptying than Rice, Potato, or Pasta. Nutrients. 10: 124.

9. Delbrassinne, LM., Rajkovic, A., Dubois, P., Nguessan, E., Mahillon, J., \& Van Loco, L. (2011) Determination of Bacillus cereus emetic toxin in food products by means of LC-MS². Food Anall Method. 5: 969-979.

10. Dierick, K., Coillie, EV., Swiecicka, I., Meyfroidt, G., Devlieger, H., Meulemans, A., Hoedemaekers, G., Fourie, L., Heyndrickx, M., \& Mahillon, J. (2005). Fatal family outbreak of Bacillus cereus associated food poisoning. Journal of Clinical Microbiology. 43: 42774279.

11. EFSA (2005). Opinion of the Scientific Panel on Biological Hazards on Bacillus cereus and other Bacillus spp in food. The EFSA J. 175: 148.

12. Ehling-Schulz, M., Frenzel, E., \& Goha, M. (2015). Food-bacteria interplay: pathometabolism of emetic Bacillus cereus. Front Microbiol. 6: 704.

13. Ehling-Schulz, M., Fricker, M., \& Scherer, S. (2004). Identification of emetic toxin producing Bacillus cereus strains by a novel molecular assay. FEMS Microbiol Lett. 232: 189 -195.

14. Ekanem, EO. (1998). The street food trade in Africa: safety and socioenvironmental issues. Food Control. 9: 211-5. 
15. Engle-Stone, R., Ndjebayi, AO., Nankap, M., \& Brown, KH. (2012). Consumption of potentially fortifiable foods by women and young children varies by ecological zone and socio-economic status in Cameroon. J Nutr. 142: 555-565.

16. Gadag, TH., Nyanga, LK., \& Mutukumira, AN. (2004). The occurrence, growth and control of pathohen in African fermented foods. AJFAND, Vol 4, $\mathrm{N}^{\circ} 1$.

17. A. (2016). Bacillus cereus-induced food-borne outbreaks in France, 2007 to 2014: Epidemiology and genetic characterisation. Eurosurveillance, 21: 30413.

18. Ghosh, S., Tano-Debrah, K., Aaron, GJ., Otoo, G., Strutt, N., Bomfeh, K., Kitamura, S., Suri, DJ., Murakami, H., Furuta, C., Sarpong, D., Saalia, F., Nakao, Y., Amonoo-Kuofi, H., Uauy, R., \& Toride, Y. (2014). Improving complementary feeding in Ghana: reaching the vulnerable through innovative business-the case of KOKO Plus. Ann N Y Acad Sci. 1331: 76-89.

19. Hanashiro, A., Morita, M., Matte, GR., Matte, MH., \& Torres, EAS. (2005). Microbiological quality of selected foods from a restricted area of Sao Paulo city, Brazil. Food Control. 16:439-44.

20. Honfoga, BG. \& van den Boom, GJ. (2003). Food-consumption patterns in central West Africa, 1961 to 2000, and challenges to combating malnutrition. Food Nutr Bull. 24:167-182.

21. Humblot, C., Pulido RP., Akaki, D., Loiseau, G., \& Guyot, JP. (2012). Prevalence and Fate of Bacillus cereus in African Traditional CerealBased Foods Used as Infant Foods. J Food Protect. 75: 1642-1645.

22. Jeon et al. (2015). Microbiological diversity and prevalence of spoilage and pathogenic bacteria in commercial fermented alcoholic beverages (beer, fruit wine, refined rice wine, and yakju). J Food Prot, 78: 812-8.

23. Kharel, N., Palni, U., \& Tamang, JP. (2016). Microbiological assessment of ethnic street foods of the Himalayas. J Ethnic Foods. 3: 235-241.

24. Kharel, N. \& Tamang, JP. (2010). Street foods: Risk and safety. J Hill Research. 23:1-9.

25. Kroten, MA., Bartoszewicz, M., \& Swiecicka, I. (2010). Cereulide and valinomycin, two important natural dodecadepsipeptides with ionophoretic activities. Pol. J. of Microbiol. 59: 3-10.

26. Mahler, H., Pasi, A., Kramer, JM., Schulte, P., Scoging, AC., Bar, W., \& Krahenbuhl, S. (1997). Fulminant liver failure in association with the emetic toxin of Bacillus cereus. N. Engl. J. Med. 336: 1142-1148.

27. Michelet, N. \& Mahillon, J. (2003). Bacillus cereus opportuniste et pathogène. Bull S. F. Microbiol. 18: 113-122. 
28. Mouquet-Rivier, C., Icard-Verniere, C., Guyot, JP., Tou, EH., Rochette, I., \& Treche, S. (2008). Consumption pattern, biochemical composition and nutritional value of fermented pearl millet gruels in Burkina Faso. Int. J. Food Sci. Nutr. 59: 716-729.

29. Naranjo, M., Denayer, S., Botteldoorn, N., Delbrassinne, L., Veys, J., Waegenaere, J., Sirtaine, N., Driesen, RB., Sipido, KR., Mahillon, J., \& Dierick, K. (2011). Sudden death of a young adult associated with Bacillus cereus food poisoning. J Clin Microbiol. 49: 4379-4381.

30. Oguntoyinbo, FA. \& Kintum, A. (2015). Toxigenic Bacillus cereus isolated from Nunu and Wara, two Nigerian fermented dairy foods. NIFOJ. 33(2).

31. Qian, Y., Kando, CK., Thorsen, L., Larsen, N., \& Jespersen, L. (2015). Production of autoinducer-2 by aerobic endospore-forming bacteria isolated from the West African fermented foods. FEMS Microbiol Lett. 362: fnv186.

32. Rajkovic, A., Uyttendaele, M., Vermeulen, A., Andjelkovic, M., FitzJames, I., in't Veld, P., Denon, Q., Verhe, R., \& Debevere, J. (2008). Heat resistance of Bacillus cereus emetic toxin, cereulide. Lett. Appl. Microbiol. 46: 536-41.

33. Schoeni, JL. \& Wong, AC. (2005). Bacillus cereus food poisoning and its toxins. J. Food Prot. 68: 636-648.

34. Shiota, M., Saitou, K., Mizumoto, H., Matsusaka, M., Agata, N., Nakayama, M., Kage, M., Tatsumi, S., Okamoto, A., Yamaguchi, S., Ohta, M., \& Hata, D. (2010). Rapid detoxification of cereulide in Bacillus cereus food poisoning. Pediatrics 125: 951- 955.

35. Thorsen, L., Abdelgadir, WS., Rønsbo, MH., Abban, S., Hamad, SH., Nielsen, DS., \& Jakobsen, M. (2010). Identification and pathogenic potential of Bacillus species occuring in high numbers during Khamirat-Al laban spontaneous fermentations. Poster session presented at 22nd Internatiional ICFMH Symposium Food Micro, Copenhagen, Denmark.

36. Thorsen, L., Kando, CK., Sawadogo, H., Larsen, N., Hendriksen, NB., \& Jespersen, L. (2015). Characteristics and phylogeny of Bacillus cereus strains isolated from Maari, a traditional West African food condiment. Int J Food Microbiol. 196: 70-78.

37. Tou, EH., Guyot, JP., Mouquet-Rivier, C., Rochette, I., Counil, E., Traore, AS., \& Treche, S. (2006). Study through surveys and fermentation kinetics of the traditional processing of pearl millet (Pennisetum glaucum) into ben-saalga, a fermented gruel from Burkina Faso.; 106:52-60.

38. Umoh, V. \& Odoba, MB. (1999). Safety and quality evaluation of street foods sold in Zaire, Nigeria. Food Control 10: 9-14. 
39. Yobouet, BA., Dadié, A., Traoré, SG., Djè, KM., \& Bonfoh, B. (2016). Contamination with Bacillus cereus of attiéké produced in the informal sector in the south of Côte d'Ivoire and risk management by the hydrothermal reheating. IJIAS. 15: 637-654.

40. Yobouet, B., Kouamé-Sina, S., Dadié, A., Makita, K ., Grace, D., Djè, K., \& Bonfoh, B. (2013). Contamination of raw milk with Bacillus cereus from farm to retail in Abidjan, Côte d'Ivoire and possible health implications. Dairy Science Technology. 94: 51-60. 